\title{
KONSELING EKSISTENSIAL DENGAN TEKNIK STRENGHT BOMBARDMENT UNTUK MENUMBUHKAN KEBERMAKNAAN PADA PASIEN SKIZOFRENIA PARANOID
}

\author{
Ahmad Chalifar Hikmawan ${ }^{1}$, Herlan Pratikto² \\ ${ }^{1}$ Program Studi Magister Psikologi Profesi, Fakultas Psikologi, Universitas 17 Agustus 1945 \\ Surabaya, Indonesia \\ 2Program Studi Magister Psikologi Profesi, Fakultas Psikologi, Universitas 17 Agustus 1945 \\ Surabaya, Indonesia \\ E-mail: chalifar16@gmail.com, pratiktoherlan75@gmail.com
}

\begin{abstract}
ABSTRAK
Skizofrenia adalah gangguan psikotik yang ditandai dengan pikiran, emosi, dan perilaku-pikiran yang terganggu. Skizofrenia dapat disebabkan oleh faktor keturunan, permasalahan psikososial, dan permasalahan dalam keluarga. Penelitian ini bersifat kualitatif dan menggunakan pendekatan studi kasus. Penelitian ini bertujuan untuk memberikan intervensi kepada pasien skizofrenia. Hasil dari observasi, wawancara, dan psikotes menunjukkan bahwa subyek mengalami halusinasi auditorik dan halusinasi berupa perasaan anggota tubuh yang sakit. Selain itu subyek juga mengalami perasaan dikejar. Berdasarkan gejala-gejala yang muncul, maka dapat disimpulkan bahwa subjek memenuhi kriteria diagnosis Skizofrenia Paranoid. Berdasarkan hasil asesmen yang diperoleh, peneliti memberikan intervensi berupa konseling eksistensial dengan teknik strength bombardment dengan tujuan untuk untuk menumbuhkan makna serta pengembangan diri subyek ke arah pertumbuhan yang lebih baik. Pelaksanaan intervensi dilakukan selama 6 hari. Hasil penelitian menunjukkan bahwa konseling eksistensial dengan teknik strenght bombardment efektif digunakan sebagai media menumbuhkan makna pada subyek. Setelah dilakukan proses intervensi subyek merasa dirinya memiliki potensi dan mampu melewati masa-masa sulit yang pernah dilaluinya.
\end{abstract}

Kata Kunci: konseling eksistensial; strength bombardment; skzofrenia paranoid.

\begin{abstract}
Schizophrenia is a psychotic disorder characterized by disturbed thoughts, emotions, and behaviorthoughts. Schizophrenia can be caused by heredity, psychosocial problems, and family problems. This research is qualitative research and uses a case study approach. This study aims to provide intervention to schizophrenic patients. The results of observations, interviews, and psychological tests showed that the subjects experienced auditory hallucinations and hallucinations in the form of feelings of sick limbs. In addition, the subject also experienced the feeling of being chased. Based on the symptoms that appear, it can be concluded that the subject meets the criteria for the diagnosis of Paranoid Schizophrenia. Based on the results of the assessment obtained, the researcher provided an intervention in the form of existential counseling with strength bombardment techniques with the aim of fostering meaning and self-development of the subject towards better growth. The intervention was carried out for 6 days. The results showed that existential counseling with the strength bombardment technique was effectively used as a medium to cultivate meaning in the subject. After the intervention process was carried out, subject felt that he had the potential and was able to get through the difficult times he had gone through.
\end{abstract}

Keywords: existential counseling; strength bombardment; schizophrenia paranoid. 


\section{PENDAHULUAN}

Pada tahun 2018, Kementerian Kesehatan mencatat bahwa 14 juta penduduk Indonesia yang berusia di atas 15 tahun mengalami depresi dan kecemasan. Pada tahun 2013 tercatat 400 ribu orang mengalami gangguan jiwa berat seperti skizofrenia (Juniman, 2018). Berdasarkan data Riskesdas tahun 2018, sebanyak 84,9\% pengidap skizofrenia/psikosis sudah mendapatkan pengobatan. Dijelaskan lebih rinci, persentase penderita psikosis yang belum mengkonsumsi obat secara teratur sebesar 48,9\%, sementara persentase penderita psikosis yang sudah meminum obat secara teratur sebesar $51,1 \%$ (Jayani, 2019).

Data WHO menunjukkan sekitar 23 juta orang mengalami skizofrenia (CNN Indonesia, 2018). Individu yang mengalami skizofrenia 2-3 kali berisiko meninggal lebih awal dibandingkan dengan individu yang tidak mengalami skizofrenia. Hal tersebut sering disebabkan oleh penyakit fisik seperti penyakit kardiovaskular, metabolisme, dan infeksi. Faktor psikososial bisa menjadi penyebab seseorang mengalami skizofrenia.

Dikutip dalam CNN Indonesia oleh Armandani (2014), di Indonesia tidak banyak dari pengidap skizofrenia yang mendapatkan penanganan medis, bahkan tak jarang banyak penderita skizofrenia yang dipasung oleh kaluarganya sendiri. Stigma negatif seringkali menyebabkan pengidap skizofrenia merasa terasing. Dikutip dari GridHealth.id oleh Saputra (2019), data Riset Kesehatan Dasar (Riskesdas) tahun 2018 menyebutkan 7 dari 1.000 rumah tangga Indonesia memiliki penderita skizofrenia. Sehingga jika terdapat 69 juta rumah tangga, maka terdapat 480.000 penderita skizofrenia.
Skizofrenia adalah gangguan psikotik yang ditandai dengan pikiran, emosi, dan perilaku-pikiran yang terganggu. Penderita skizofrenia biasanya mengalami permasalahan dalam proses berpikir, serta permasalahan atau gangguan dalam afeksi dan motorik. Pengidap skizofrenia seringkali mengalami delusi dan halusinasi, serta menunjukkan perilaku menarik diri dari oranglain dan kenyataan. Individu usia remaja akhir dan dewasa awal rentan mengalami skizofrenia (Davison, Neale, \& Kring, 2018). Menurut Handayani et.al (2015) faktor risiko dari skizofrenia dapat berupa faktor keturunan, stresor psikososial dari masalah hubungan interpersonal, dan faktor keluarga.

Penelitian ini bertujuan untuk memberikan intervensi kepada pasien skizofrenia paranoid. Intervensi yang dilakukan adalah konseling eksistensial dengan teknik strength bombardment.

Alasan pemilihan intervensi ini karena subyek sering merasakan kegagalan dalam hidupnya. Subyek sering berdiam diri dan mulai timbul perilaku yang tidak wajar akibat sering memikirkan kegagalannya. Dengan mengingat keberhasilan dan kekuatan, serta potensi dalam diri subyek maka hal tersebut akan membantu subyek dalam memperbaiki gambaran dirinya dan dapat menjadi sumber resiliensi di masa mendatang. Menurut Sabrina (2016) konseling eksistensial dapat menumbuhkan hal-hal positif seperti potensi, tujuan, harapan, dan keyakinan pada pasien skizofrenia.

Menurut May, pendekatan eksistensial sangat menekankan pada keberadaan atau eksistensi manusia. Sehingga manusia akan merasa bermakna karena eksistensi atau keberadaannya dengan menunjukkan hal-hal positif pada dirinya (Corey dalam Sabrina, 
2016). Dijelaskan lebih lanjut oleh Olson dan Hergenham, konseling dengan pendekatan eksistensial dari Rollo May dapat membantu klien menemukan makna. Konselor membimbing klien agar dapat menemukan potensi dirinya. Sehingga klien dapat menerima diri dan memaknai hidupnya dengan cara yang positif (dalam Sabrina, 2016).

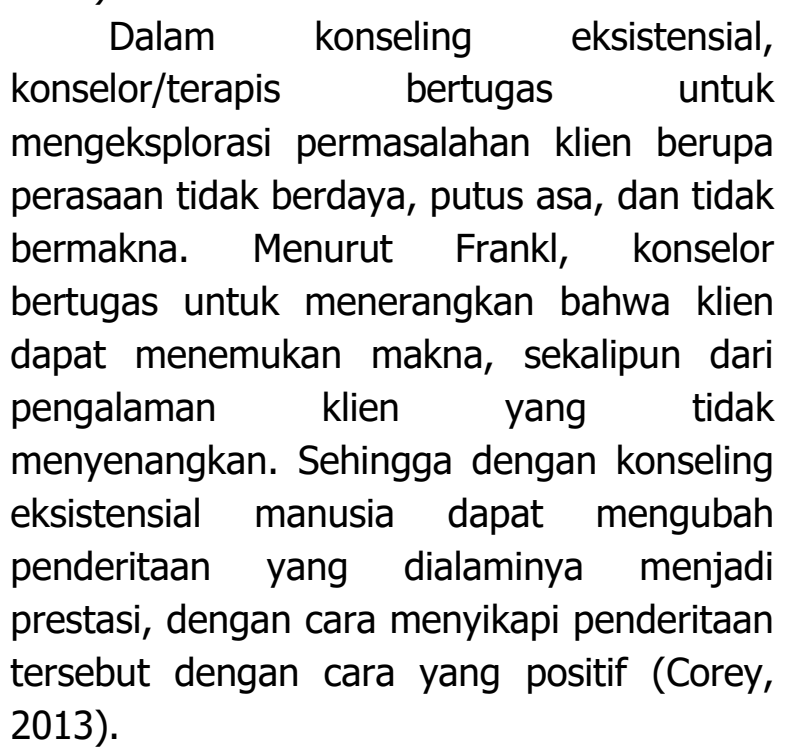

Teknik strength bombardment berasal dari paradigma humanistik-eksistensial dan juga, dalam tingkat lebih rendah, paradigma kognitif behavioral. Menurut Steele (dalam Erford, 2017), premis yang mendasari penggunaan teknik strength bombardment adalah suasana perasaan (mood), persepsi tentang diri (self-perception), dan gambaran tentang diri (self-image) bisa membaik jika klien menerima komunikasi berbasis kekuatan dari orang lain dan kemudian menginternalisasikan komunikasi tersebut ke dalam dialog batiniahnya sendiri.

Strengh bombardment membentuk persepsi dan perasaan klien saat ini. Setelah persepsi dan perasaan berbasis kekuatan terinternalisasi, mereka dapat digunakan sebagai sumber resiliensi ketika klien mengalami peristiwa yang membuat dirinya resah atau mengalami traumatik di masa mendatang. Strenght bombardment dapat digunakan di dalam situasi konseling individual atau kelompok-kecil (Erford, 2017).

Steele menyebutkan bahwa strength bombardment digunakan dalam konseling individual sebagai sebuah teknik afirmasidiri. Afirmasi-diri dapat digunakan secara kombinasi dengan teknik pengecualian (exception technique). Untuk mengimplementasikan strength bombardment (afirmasi-diri) pada seorang klien, konselor meminta klien untuk mengingat saat-saat atau situasi-situasi di mana klien menemui tantangan atau masalah serupa namun ia berhasil, atau paling tidak sebagian berhasil menangani situasinya. Kemudian meminta klien untuk fokus dan membantu klien untuk mengidentifikasi dan mengkompilasi daftar kekuatan dan karakteristik kesuksesan yang didemonstrasikan selama peristiwa-peristiwa tersebut (dalam Erford, 2017).

Gejala-gejala yang mencolok dari skizofrenia paranoid yaitu waham primer yang disertai dengan waham sekunder dan halusinasi. Penderita skizofrenia paranoid juga mengalami gangguan proses berpikir, gangguan perasaan, serta gangguan emosi. Perasaan negatif seperti mudah tersinggung dan kurang mempercayai orang lain juga sering dialami oleh pasien skizofrenia paranoid. Selain itu penderita skizofrenia paranoid juga sering menyendiri dan bersikap agak congkak (Maramis \& Maramis, 2012).

Individu dapat didiagnosis mengalami skizofrenia apabila dalam kurun waktu minimal satu bulan mengalami satu dari kriteria umum gejala berikut, yaitu gangguan isi pikiran, waham, dan halusinasi auditorik; 
atau paling sedikit mengalami dua gejala berikut, yaitu halusinasi yang berasal dari panca indera secara menetap, terputusnya arus pikiran (break), perilaku katatonik (gaduh gelisah), respons emosional yang tidak wajar, dan disertai perilaku menarik diri (Maslim, 2013).

Individu dapat dikatakan mengalami skizofrenia paranoid apabila memmenuhi kriteria umum diagnosis skizofrenia, namun harus disertai dengan gejala-gejala tambahan yaitu halusinasi yang dapat berupa halusinasi auditorik, halusinasi terkait penginderaan atau perasaan tubuh, atau halusinasi yang bersifat seksual; disertai dengan waham dan gangguan dalam hal afektif, dorongan kehendak dan pembicaraan, serta gejala perilaku katatonik (Maslim, 2013).

\section{METODE PENELITIAN}

Penelitian ini bersifat kualitatif dengan menggunakan pendekatan studi kasus. Penelitian ini dilakukan terhadap seorang pasien Rumah Sakit Jiwa (RSJ) yang mengalami skizofrenia. Subyek penelitian berusia 52 tahun. Subyek penelitian ini adalah seorang pasien RSJ yang mengalami skizofrenia. Subyek berusia 52 tahun. Intervensi yang dilakukan dalam penelitian ini berupa konseling eksistensial dengan teknik strength bombardment.

Proses pengambilan data dalam penelitian ini dilakukan dengan metode observasi, wawancara, tes psikologi, dan studi dokumentasi. Selanjutnya peneliti menganalisa data-data yang sudah diperoleh sebagai dasar untuk mendiagnosa dan merancang intervensi yang sesuai untuk subyek.

\begin{tabular}{|c|c|c|}
\hline $\begin{array}{l}\text { Pengambilan Data: } \\
\text { - Observasi } \\
\text { - } \quad \text { Tes Psikologi } \\
\text { - } \quad \text { Studi Dokumentasi }\end{array}$ & $\begin{array}{l}\text { Hasil Asesmen: } \\
\text { Diagnosis: } \\
\text { Skizofrenia Paranoid } \\
\text { (F20.0) }\end{array}$ & $\begin{array}{l}\text { Intervensi: } \\
\text { Konseling Eksistensial } \\
\text { dengan Teknik Strength } \\
\text { bombardment }\end{array}$ \\
\hline
\end{tabular}

\section{Gambar 1. Proses Pelaksanaan Penelitian}

Jenis intervensi yang di gunakan adalah konseling dengan pendekatan humanis- eksistensial dengan menggunakan teknik strength bombardment. Intervensi yang dilakukan terdiri dari lima tahap, yaitu:

Tahap 1 yaitu membangun rapport dan menetapkan tujuan. Pada Tahap ini peneliti membangun rapport dengan subyek serta menjelaskan dan menetapkan tujuan intervensi.

Tahap 2 yaitu menggali hal-hal positif dari subyek. Pada tahap ini peneliti mengajak subyek untuk mengingat hal-hal positif yang pernah dialami dan dimiliki oleh subyek. Pada tahap inquiry dan konseling di Tahap 2 praktikan mendalami informasi yang didapatkan dari klien, serta melakukan konseling.

Tahap 3 yaitu pencarian potensi. Pada tahap ini peneliti mengajak subyek untuk mencari kelebihan pada diri subyek sehingga dapat berkembang menjadi potensi. Pada tahap inquiry dan konseling yang dilakukan di Tahap 3 praktikan Mendalami potensi yang dimiliki subyek serta mengetahui rencana terkait potensi yang dimilikinya. 
Tahap 4 yaitu inquiry permasalahan subyek. Pada tahap ini praktikan menggali informasi mengenai apa yang dirasakan oleh subyek ketika mengalami masa-masa sulit.

Tahap 5 yaitu evaluasi dan terminasi. Pada Tahap ini praktikan menanyakan tabel perasaan subyek setelah proses intervensi, serta rencana yang akan dilakukan klien setelah pulang dari RSJ.

Tujuan dan terget dari masing-masing tahapan intervensi dijelaskan lebih rinci pada

Tabel 1. Tujuan dan Target Intervensi

\begin{tabular}{|c|c|c|}
\hline Tahapan & Tujuan & Target \\
\hline $\begin{array}{l}\text { Tahap } 1 \\
\text { Building rapport } \\
\text { dan penetapan } \\
\text { tujuan }\end{array}$ & $\begin{array}{l}\text { Menjalin kedekatan dan } \\
\text { menumbuhkan kepercayaan antara } \\
\text { praktikan dengan klien. }\end{array}$ & $\begin{array}{l}\text { Klien mampu } r \begin{array}{r}\text { untuk } \\
\text { bekerjasama }\end{array} \text { dengan } \\
\text { praktikan selama proses } \\
\text { intervensi serta memahami } \\
\text { tujuan dari intervensi. }\end{array}$ \\
\hline $\begin{array}{l}\text { Tahap } 2 \\
\text { Menggali hal-hal } \\
\text { positif dari diri } \\
\text { klien }\end{array}$ & $\begin{array}{l}\text { Klien mengungkapkan hal-hal positif } \\
\text { (kebanggaan) yang dimilikinya. }\end{array}$ & $\begin{array}{l}\text { Mendapatkan informasi } \\
\text { mengenai kelebihan atau hal- } \\
\text { hal yang dibanggakan oleh } \\
\text { klien. }\end{array}$ \\
\hline Inquiry & $\begin{array}{l}\text { Menggali informasi terkait dengan } \\
\text { hal-hal yang dibanggakan dalam diri } \\
\text { klien. }\end{array}$ & $\begin{array}{l}\text { Mendapatkan informasi } \\
\text { secara mendalam mengenai } \\
\text { hal-hal yang dibanggakan } \\
\text { dari klien. }\end{array}$ \\
\hline Sesi konseling & Memberikan konseling kepada klien. & $\begin{array}{lrr}\text { Klien } & \text { menjadi } & \text { lebih } \\
\text { memahami } & \text { positif } & \text { dalam } \\
\text { dirinya. } & & \\
\end{array}$ \\
\hline $\begin{array}{l}\text { Tahap } 3 \\
\text { Pencarian potensi }\end{array}$ & $\begin{array}{l}\text { Menyadarkan klien akan potensi } \\
\text { yang dimilikinya. }\end{array}$ & $\begin{array}{l}\text { Klien mulai menyadari } \\
\text { potensi yang dimilikinya. }\end{array}$ \\
\hline Inquiry & $\begin{array}{l}\text { Menggali informasi terkait dengan } \\
\text { kelebihan pada diri klien. }\end{array}$ & $\begin{array}{l}\text { Mendapatkan informasi } \\
\text { mengenai kelebihan pada diri } \\
\text { klien. }\end{array}$ \\
\hline Sesi konseling & Memberikan konseling kepada klien. & $\begin{array}{l}\text { Klien dapat menyadari } \\
\text { kelebihannya dan mampu } \\
\text { mengembangkannya menjadi } \\
\text { potensi. }\end{array}$ \\
\hline $\begin{array}{l}\text { Tahap } 4 \\
\text { Inquiry } \\
\text { permasalahan } \\
\text { yang } \\
\text { teridentifikasi }\end{array}$ & $\begin{array}{l}\text { Untuk mengetahui informasi lebh } \\
\text { dalam mengenai bagaimana } \\
\text { perasaan dan reaksi klien terhadap } \\
\text { permasalahan yang terjadi, serta } \\
\text { cara klien menyikapi masalah } \\
\text { tersebut. }\end{array}$ & $\begin{array}{l}\text { Mendapatkan } \quad \text { informasi } \\
\text { secara mendalam mengenai } \\
\text { permasalahan yang dialami } \\
\text { oleh klien. }\end{array}$ \\
\hline Penemuan makna & $\begin{array}{l}\text { Menggali informasi bagaimana klien } \\
\text { memaknai permasalahan yang } \\
\text { dihadapinya. }\end{array}$ & $\begin{array}{l}\text { Mendapatkan informasi } \\
\text { menganai bagaimana klien } \\
\text { memaknai permasalahan } \\
\text { yang dihadapinya. }\end{array}$ \\
\hline Sesi konseling & Memberikan konseling kepada klien. & $\begin{array}{l}\text { Klien mampu mendapatkan } \\
\text { insight dari permasalahan } \\
\text { yang dihadapinya }\end{array}$ \\
\hline
\end{tabular}




\section{Tahap 5}

Evaluasi dan

terminasi
Menanyakan perasaan klien sebelum dan sesudah intervensi, serta hasil yang didapat klien setelah intervensi.
Klien mendapatkan hasil dari intervensi yang dilakukan selama beberapa hari. Klien merasa lega dan menyadari kekuatan pada dirinya. Klien mengutarakan rencana ke depannya dan apa yang akan dilakukan ketika menghadapi masa-masa sulit.

\section{HASIL DAN PEMBAHASAN}

Hasil penelitian meunjukkan subyek mengalami halusinasi auditorik berupa suara perempuan yang mengajak berbicara. Subyek juga mengalami halusinasi berupa perasaan anggota tubuh yang sakit, seperti pusing dan pegal. Hasil observasi menunjukkan subyek terlihat lebih sering menyendiri. Subyek juga sering merasa gelisah yang membuat dirinya sering mondar-mandir. Selain itu subyek juga mengalami perasaan dikejar. Berdasarkan gejala-gejala yang muncul, maka dapat disimpulkan bahwa subyek mengalami Skizofrenia Paranoid.

Gejala-gejala tersebut sesuai dengan pedoman diagnosis skizofrenia berdasarkan PPDGJ-III, yaitu (1) adanya gangguan isi pikiran; (2) halusinasi auditorik; (3) perilaku katatonik; dan (4) munculnya gejala-gejala negatif yang dilihat dari sikap, arus pembicaraan, respons emosional, interaksi sosial, dan keterlibatan dalam aktivitas sosial. Gejala-gejala tersebut juga diperkuat dengan pedoman diagnosis tipe Skizofrenia Paranoid dalam PPDGJ-III (F 20.0), yaitu (1) suara-suara halusianasi yang mengancam, berdengung (humming), berbunyi seperti pluit (whistling), atau suara seseorang sedang tertawa (laughing); (2) halusinasi terkait panca indera dan perasaan tubuh, atau halusinasi yang bersifat seksual; serta
(3) waham dan keyakinan "dikejar-kejar" (Maslim, 2013).

Penyabab subyek mengalami skizofrenia paranoid disebabkan oleh masalah dengan keluarga dan lingkungan sosial, serta masalah dengan pekerjaan atau kesulitan ekonomi. Menurut Erlina, Soewadi, dan Pranowo (2010) faktor psikososial seperti sosial ekonomi yang rendah dan stres lingkungan dapat menyebabkan seseorang mengalami skizofrenia.

Subyek sering merasa dirinya tidak berharga dan tidak diperhatikan. Berdasarkan wawancara dengan subyek dan keluarga subyek, subyek sudah dirawat di RSJ sebanyak tiga kali. Subyek seringkali marah-marah dan menunjukkan sikap memusuhi orang lain. Subyek mengalami konflik kebermaknaan karena merasa dirinya gagal menjadi kepala rumah tangga. Subyek merasa dirinya tidak dapat menafkahi keluarganya. Sebagaimana yang dikemukakan oleh Eklund, Hermansson, dan Hakansson (2012) penderita skizofrenia sering memiliki permasalahan terkait ketidakbermaknaan dalam kehidupan mereka. Penderita skizofrenia sering merasa pasif dan merasa kesepian. Seringkali banyak penderita skizofrenia yang ditolak dari lingkungan sosial dan kehilangan pekerjaannya. Sehingga pengalamanpengalaman tersebut dapat memperngaruhi kebermaknaan hidup mereka. 
Ahmad Chalifar Hikmawan, Herlan Pratikto Jurnal Consulenza:Jurnal Bimbingan Konseling dan Psikologi Volume 4, Nomor 1, Tahun Edisi 2021, Halaman 30-40 e-ISSN 2623-033X, p-ISSN 2623-0348

Penjelasan secara mendetail mengenai ditampilkan pada tabel 2. kegiatan dan hasil intervensi pada setiap sesi

Tabel 2. Pelaksanaan Intervensi

\begin{tabular}{llrl}
\hline \multicolumn{1}{c}{ Tahapan } & \multicolumn{2}{c}{ Kegiatan } & \multicolumn{1}{c}{ Hasil } \\
\hline Tahap 1 & Membangun rapport & serta & Rapport antara subyek dengan peneliti \\
Building & menjelaskan & dan & sudah terbangun dengan baik. Subyek \\
rapport dan & menetapkan & tujuan & bersedia untuk berkomitmen terhadap \\
penetapan & intervensi. & & proses intervensi dan memahami tujuan \\
tujuan & & & dari pelaksanaan intervensi.
\end{tabular}

Tahap 2 Mengajak subyek untuk Didapatkan hal-hal positif dari diri Menggali hal- mengingat hal-hal positif subyek, diantaranya (1) subyek hal positif dari yang pernah dialami dan mendapatkan ranking saat SD, (2) diri subyek dimiliki oleh klien.

subyek masih mampu menghasilkan nafkah ditengah masa-masa sulit, (3) subyek rajin membantu orangtua, dan (4) subyek merasa senang bisa bermain sepak bola dengan temannya.

Inquirydan Mendalami informasi yang Subyek mengatakan bahwa dirinya sesi konseling didapatkan dari subyek, serta melakukan konseling. merasa bangga karena anak-anaknya bisa sekolah tak lepas dari usaha klien. Subyek menyadari bahwa dirinya merasa masih beruntung karena masih bisa mendapatkan penghasilan di masa-masa sulit. Selaint itu subyek menyadari bahwa dirinya bukanlah orang yang mudah menyerah dan masih bisa membantu orangtuanya.

\begin{tabular}{|c|c|c|}
\hline $\begin{array}{l}\text { Tahap } 3 \\
\text { Pencarian } \\
\text { potensi }\end{array}$ & $\begin{array}{l}\text { Peneliti mengajak } r \text { subyek } \\
\text { untuk mencari kelebihan } \\
\text { pada diri subyek sehingga } \\
\text { dapat berkembang menjadi } \\
\text { potensi. }\end{array}$ & $\begin{array}{l}\text { Subyek menyadari kalau sebenarnya ia } \\
\text { memiliki kemampuan untuk beternak. } \\
\text { Subyek merasa bahwa memelihara } \\
\text { binatang merupakan hobinya yang bisa } \\
\text { dijadikan potensi. }\end{array}$ \\
\hline $\begin{array}{l}\text { Inquiry dan } \\
\text { sesi konseling }\end{array}$ & $\begin{array}{llr}\text { Mendalami } & \text { potensi } & \text { yang } \\
\text { dimiliki } & \text { subyek } & \text { serta } \\
\text { mengetahui } & \text { rencana } & \text { terkait } \\
\text { potensi yang dimilikinya. }\end{array}$ & $\begin{array}{l}\text { Subyek berencana untuk kembali bekerja } \\
\text { keras di penggilingan padi. Jika dirinya } \\
\text { memiliki kesempatan dan peluang untuk } \\
\text { memulai beternak, klien akan } \\
\text { mencobanya }\end{array}$ \\
\hline $\begin{array}{l}\text { Tahap } 4 \\
\text { Inquiry } \\
\text { permasalahan } \\
\text { klien }\end{array}$ & $\begin{array}{l}\text { Menggali informasi terkait } \\
\text { apa yang dirasakan oleh } \\
\text { subyek ketika menghadapi } \\
\text { masa-masa sulit. }\end{array}$ & $\begin{array}{l}\text { Subyek mengatakan bahwa masalah di } \\
\text { tempat kerja dan perceraian merupakan } \\
\text { masa-masa tersulit dalam hidupnya. } \\
\text { Subyek merasa hidupnya tidak menentu } \\
\text { dan merasa gagal dalam menjalankan } \\
\text { perannya sebagai ayah }\end{array}$ \\
\hline Penemuan & Menggali & Subyek merasa masih dapat menerima \\
\hline
\end{tabular}




\begin{tabular}{ll}
\hline makna & $\begin{array}{l}\text { bagaimana cara subyek } \\
\text { memaknai masa-masa sulit. }\end{array}$ \\
& \\
\hline Sesi konseling & $\begin{array}{l}\text { Memberikan konseling } \\
\text { kepada subyek terkait } \\
\text { masalah yang dihadapinya. }\end{array}$
\end{tabular}

keadaannya setelah dikeluarkan dari tempat kerjanya. Subyek mengatakan bahwa masa-masa sulit dalam pekerjaan sama seperti sekolah, dan subyek merasa bisa belajar untuk lebih baik lagi kedepannya. Namun pada sesi ini subyek masih sulit untuk menerima keadaannya setelah bercerai dengan istrinya

Subyek menyadari bahwa dirinya mampu untuk melewati masa-masa sulit. Subyek menyadari bahwa dengan masa-masa sulit terkait dengan kehilangan pekerjaannya dirinya ingin belajar untuk bekerja lebih baik lagi dan tetap bekerja keras.

Subyek dapat memaknai perceraian yang pernah dialaminya sebagai proses belajar, sehingga kedepannya subyek akan berusaha untuk menjaga hubungan baik dengan keluarganya.

Subyek mengatakan bahwa masa-masa sulit yang dialaminya seperti sekolah, dan mengatkan bahwa jika dirinya mampu untuk mengatasi masa-masa sulit maka kita akan mencapai hasil yang gemilang

\section{Tahap 5}

Evaluasi dan terminasi

\section{Menanyakan}

subyek setelah

perasaan

intervensi, serta rencana yang akan dilakukan setelah keluar dari RSJ.

\section{Subyek mengatakan bahwa perasaannya} sudah lega setelah mengikuti arahan dari peneliti selama proses intervensi. Subyek merasa dirinya mendapat dukungan dari peneliti. Subyek berencana untuk kembali bekerja di penggilingan padi karena pekerjaan tersebut dekat dengan tempat tinggalnya, atau memulainya dengan pekerjaan yang mudah. Subyek berencana untuk kembali berkumpul dan memperbaiki hubungan dengan keluarga. Selain itu, subyek juga berencana untuk kembali menemui anakanaknya. Subyek tidak mau kembali lagi ke RSJ, oleh karena itu subyek akan berusaha untuk belajar dari masa-masa sulit yang dialaminya untuk bisa lebih baik lagi. 
Dari hasil intervensi berupa konseling eksistensial dengan teknik strength bombardment yang sudah diberikan kapada subyek yang dilakukan selama enam hari, konseling eksistensial dengan teknik strength bombardment cukup efektif untuk mengatasi konflik kebermaknaan pada subyek. Subyek yang awalnya merasa dirinya tidak memiliki kelebihan dan belum menyadari potensi dirinya merasa dirinya memiliki potensi dan mampu untuk melewati masa-masa sulit yang pernah dialaminya. Untuk memahami lebih detail hasil dari intervensi konseling eksistensial yang dilakukan, dijelaskan pada tabel 3 .

\section{Tabel 3. Hasil Intervensi}

\section{Sebelum Intervensi}

Sebelum dilaksanakan intervensi, subyek merasa bahwa dirinya tidak memiliki kelebihan dan belum menyadari potensi pada dirinya.

Subyek sering merasa hidupnya penuh ketidakpastian dan sering merasakan kegagalan dalam hidupnya. Subyek merasa dirinya gagal dalam pekerjaan dan rumah tangga. Bahkan subyek merasa bahwa dirinya tidak pantas mengasuh anak-anaknya karena tidak dapat memberikan nafkah bagi keluarganya. yang dilakukan oleh Sabrina (2016), di mana konseling eksistensial efektif untuk menumbuhkan kebermaknaan pada penderita skizofrenia. Subyek mampu untuk mengenali potensi dirinya sehingga dapat berkembang ke arah yang positif. Steele mengemukakan bahwa strength bombardment dapat digunakan sebagai teknik afirmasi-diri (Erford, 2017). Subyek mampu untuk mengingat keberhasilan dirinya dalam mengatasi masa-masa sulit. Subyek menyadari dirinya masih mampu untuk menghasilkan nafkah ditengah masamasa sulit. Subyek juga menyadari dan merasa bangga bahwa kedua anaknya bisa sekolah berkat usaha subyek dalam menafkahi keluarga. Sehingga hal-hal positif
Setelah Intervensi

Setelah proses intervensi subyek merasa dirinya lebih lega. Subyek juga merasa mendapat dukungan dari praktikan selama proses intervensi. Subyek menyadari bahwa dirinya memiliki potensi dan mampu untuk melewati masa-masa sulit. Setelah pulang dari RSJ, subyek berencana untuk menemui keluarganya dan ingin menjalani kehidupan dengan orang-orang terdekatnya dengan lebih baik lagi. Subyek juga merasa siap untuk kembali bekerja di dekat tempat tinggalnya. Subyek juga berencana untuk kembali menemui anak-anaknya.

tersebut dapat dijadikan sebagai sumber kekuatan untuk subyek.

\section{SIMPULAN}

Hasil penelitian menunjukkan konseling eksistensial dengan teknik strength bombardment efektif untuk menumbuhkan kebermaknaan dalam diri subyek. Secara teoritis konseling dengan pendekatan eksistensial dapat memberikan kesadaran kepada klien akan hal-hal positif pada dirinya. Teknik strength bombarment yang digunakan dalam proses konseling juga dapat menjadi sumber resiliensi ketika subyek mengalami peristiwa meresahkan dan traumatik di masa mendatang. Dengan mengingat hal-hal positif maka subyek dapat 
memperbaiki gambaran dirinya menjadi lebih positif.

Kendala yang ditemui oleh peneliti dalam penelitian ini adalah, terkadang subyek sulit untuk terbuka dengan permasalahannya. Selain itu sebagaimana yang dikemukakan oleh Erford (2017) penelitian terkait dengan teknik strength bombardment masih sedikit. Oleh karena itu diperlukan penelitian lebih lanjut mengenai efektivitas teknik strength bombardment terutama untuk kasus skizofrenia di Indonesia. Selain itu intervensi dengan teknik dan pendekatan lain untuk menangani pasien dengan skizofrenia perlu untuk dipertimbangkan.

Berdasarkan hasil penelitian disarankan bagi subyek untuk menerapkan teknik strength bombardment dengan mengingat dan mencatat hal-hal positif yang telah subyek lakukan, serta mengingat keberhasilan subyek ketika berhasil melewati masa-masa sulit. Subyek juga perlu untuk mengisi waktu luangnya dengan aktivitas yang sederhana, seperti membantu melakukan pekerjaan rumah tangga atau membantu mengurus hewan peliharaan milik keluarga. Subyek disarankan untuk mencari pekerjaan yang ringan atau pekerjaan yang bisa dilakukan di sekitar tempat tinggal subyek. Subyek sebaiknya menghindari aktivitas atau pekerjaan yang melibatkan benda tajam agar tidak membahayakan diri subyek dan orang lain. Jika subyek mengalami masalah subyek perlu untuk segera menceritakannya kepada keluarga atau orang terdekat subyek agar orang terdekat subyek dapat membantu subyek untuk menyelesaikan masalah demi kebaikan subyek. Subjek juga perlu untuk meminum obat secara teratur.

Saran kepada keluarga subyek, yaitu keluarga diharapkan mampu membantu proses pemulihan subyek dengan cara memberikan dukungan untuk subyek. Jika subyek sedang tidak bekerja sebaiknya keluarga perlu untuk mengajak subyek melakukan kegiatan/aktivitas yang ringan, seperti membantu melakukan pekerjaan rumah tangga atau membantu mengurus hewan peliharaan keluarga subyek. Tidak melibatkan subyek pada pakerjaan yang menggunakan benda tajam demi keamanan dirinya dan orang di sekitarnya. Keluarga perlu untuk terbuka terhadap permasalahan yang dialami oleh subyek. Mengingatkan subyek untuk meminum obat sesuai dengan anjuran.

Saran untuk pihak rumah sakit yaitu memberikan contoh yang positif dan mendukung pemulihan subyek, mengingatkan subyek untuk minum obat secara teratur, dan membangun ruang untuk asesmen di ruang perawatan pasien.

\section{DAFTAR PUSTAKA}

Armandani, K. (2014, Oktober 13). Nasib Pengidap Skizofrenia di Indonesia. Diakses dari: https://www.cnnindonesia.com/gayahidup/20141013140407-2556179/nasib-pengidap-skizofrenia-diindonesia

CNN Indonesia. (2018, Oktober 10). WHO: 23 Juta Warga Dunia Idap Skizofrenia. Diakses dari https://www.cnnindonesia.com/gayahidup/20181010111644-255337224/who-23-juta-warga-duniaidap-skizofrenia

Corey, G. (2013). Teori dan praktek Konseling \& Psikoterapi. Bandung : PT Refika Aditama.

Davison, G. C., Neale, J. M., Kring, M A. (2010). Psikologi Abnormal (edisi ke- 
Ahmad Chalifar Hikmawan, Herlan Pratikto Jurnal Consulenza: Jurnal Bimbingan Konseling dan Psikologi Volume 4, Nomor 1, Tahun Edisi 2021, Halaman 30-40 e-ISSN 2623-033X, p-ISSN 2623-0348

9). Jakarta : PT. Raja Grafindo Persada.

Eklund, M., Hermansson, A., \& Hakansson, C. (2012). Meaning in life for people with schizophrenia: Does it include occupation?. Journal of Occupational Science, 19(2), 93-105. Diunduh dari http://dx.doi.org/10.1080/14427591.2 011.605833

Erford, B. T. (2017). 40 Teknik yang Harus Diketahui Setiap Konselor (edisi ke-2). Yogyakarta : Pustaka Belajar.

Erlina, Soewadi, \& Pramono, D. (2010). Determinan terhadap timbulnya skizofrenia pada pasien rawat jalan di Rumah Sakit Jiwa Prof. HB Saanin Padang Sumatera Barat. Berita Kedokteran Masyarakat, 26(2), 71-80.

Feist, J., \& Feist, G. J. (2009). Theories of personality (7th ed.). New York, NY: McGraw-Hill.

Handayani, L., Febriani, Rahmadani, A., \& Saufi, A. (2015). Faktor kejadian skizofrenia di Rumah Sakit Jiwa Grhasia Daerah Istimewa Yogyakarta (DIY). Humanitas, 13(2), 135-148.

Jayani, D. H. (2019, 8 Oktober). Persebaran Prevalensi Skizofrenia/Psikosis di Indonesia. Diunduh dari https://databoks.katadata.co.id/datapu blish/2019/10/08/persebaranprevalensi-skizofreniapsikosis-diindonesia

Juniman, P. T. (2018, September 10). 15,8 Persen Keluarga Hidup dengan Penderita Gangguan Mental. Diakses dari https://www.cnnindonesia.com/gayahidup/20180830182931-255-

326289/158-persen-keluarga-hidupdengan-penderita-gangguan-mental

Maramis, W. F., Maramis, A. A. (2012). Catatan ilmu kedokteran jiwa (edisi ke-
2). Surabaya: Airlangga University Press.

Maslim, R. (2013). Diagnosis Gangguan Jiwa (Rujukan dari PPDGJ III dan DSM 5). Jakarta : PT Nuh Jaya

Sabrina, R. (2016). Konseling eksistensial untuk meningkatkan kebermaknaan hidup pada penderita skizofrenia : studi kasus. Seminar Asean 2nd Psychology \& Humanity, 379-385. Diunduh dari: http://mpsi.umm.ac.id/files/file/379385\%20Rizqa\%20Sabrina.pdf

Saputra, A. (2019, Oktober 7). Akibat Kurangnya Pemahaman Medis, Banyak Pengidap Skizofrenia di Indonesia Hidup Menggelandang dan Dipasung. Diakses dari https://health.grid.id/read/351876413/ akibat-kurangnya-pemahaman-medisbanyak-pengidap-skizofrenia-diindonesia-hidup-menggelandang-dandipasung?page $=$ all

Widyastana, M. H., \& Zahro, I. F. (2018). Kebermaknaan hidup narapidana ditinjau dari pendekatan eksistensial. Jurnal Psikologi, 5(1), 1-10. 